\title{
THE EFFECT OF ERYTHROPOIETIN ON PLATELET DISTRIBUTION WIDTH DURING ISCHEMIA REPERFUSION INJURY IN RATS
}

\author{
Constantinos TSOMPOS*, Constantinos PANOULIS**, Konstantinos TOUTOUZAS***, \\ George ZOGRAFOS***, Apostolos PAPALOIIS*** $^{* * *}$ \\ *Department of Obstetrics \& Gynecology, Mesologi County Hospital \\ **Department of Obstetrics \& Gynecology, Aretaieio Hospital \\ ***Department of Surgery, Ippokrateio Hospital \\ ****Elpen Pharmaceuticals S.A., Co., Inc.
}

\begin{abstract}
OBJECTIVE: Aim of this experiment study was the erythropoietin (Epo) testing, on rat model and particularly on ischemia reperfusion protocol. The benefit or the non effect of that molecule was studied hematologically on platelet distribution width (PDW).

MATERIAL and METHODS: 40 rats were used of mean weight 247,7 gr. PDW was measured at these time points: on 60 min after reperfusion (groups $\mathrm{A}$ and $\mathrm{C}$ ), and on 120 min after reperfusion (groups B and D), A and B without but C and D with Epo administration.

RESULTS: Epo administration increased significantly the PDW levels by $0.22 \%$ [0.034374 \% - 0.4056259 \%] (P= 0.0214), in accordance also with paired t-test $(\mathrm{P}=0.0196)$. Reperfusion time decreased significantly the PDW levels by $0.27 \%$ [$0.4483669 \%-0.0916332 \%](\mathrm{P}=0.0040)$, in accordance also with paired t-test $(\mathrm{P}=0.0012)$. Interaction of Epo administration and reperfusion time increased non significantly the PDW levels by $0.06 \%$ [-0.054648 \% - $0.1819207 \%]$ $(\mathrm{P}=0.0615)$.

CONCLUSION: Epo administration has significant increasing short-term effects on PDW levels. However, reperfusion time attenuates significantly this effect. Their interaction seems to resemble the action of Epo administration. The following question is whether these PDW levels alterations are the cause or the result of diseases process modification.
\end{abstract}

Key Words: Erythropoietin, platelet distribution width, reperfusion.

\section{RATLARDA İSKEMİ REPERFÜZYON SIRASINDA PLATELET DAĞILIM GENIŞLİĞİNDE}

\section{ERITTROPOIETININ ETKISİ}

\section{ÖZET}

AMAÇ: Bu deneysel çalışmanın amacı rat modelinde, özellikle de iskemi reperfüzyon protokolünde, eritropoietini (Epo) test etmekti. Ayrıca molekülün platelet dağılım genişliği (PDW) üzerindeki faydası veya etkisi araştırıldı.

GEREC ve YÖNTEM: Ortalama 247,7 gram ağırlığında 40 rat kullanıldı. PDW, reperfüzyon sonrası 60. dakikada (grup A ve C) ve 120. dakikada (grup B ve D) ölçüldü, A ve B gruplarına değil, C ve D gruplarına Epo uygulandı.

BULGULAR: Epo uygulaması eșleștirilmiş t-testi ile uyumlu olarak ( $\mathrm{P}=0.0196), 2)$, PDW düzeylerini \%0.22 oranında anlamlı şekilde arttırdı [0.034374\% - $0.4056259 \%](\mathrm{P}=0.0214)$, eşleștirilmiş t-testi ile uyumlu olarak $(\mathrm{P}=0.0012), 3)$, reperfüzyon süresi PDW düzeylerini anlamlı șekilde \%0.27 oranında azalttı, Epo uygulaması ve reperfüzyon süresi arasındaki etkileşim PDW düzeylerini \% 0.06 oranında arttırdı (anlamlı değil) [-0.054648 \% - $0.1819207 \%](P=0.0615)$. SONUÇ: Epo uygulaması PDW düzeylerinin kısa süreli etkilerinde anlamlı bir artışa neden olur. Ancak, reperfüzyon süresi bu etkiyi anlamlı derecede zayıflatır. Bunların etkileşimi Epo uygulamasının etkisine benzemektedir. PDW düzeylerindeki değişiklikler hastalık sürecinin değişmesinin bir nedeni midir veya sonucu mudur sorusuna yanıt aranmalıdır.

Anahtar Sözcükler: Eritropoietin, platelet dağılım genişliği, reperfüzyon.

Corresponding author: Constantinos Tsompos, MD. Mesologi County Hospital Department of Obstetrics \& Gynecology, Greece.

Telephone: $00302106107867 \quad$ E-mail: constantinostsompos@yahoo.com

Received: 22.08.2013 Accepted: 13.11.2013

This article should be cited as following: Tsompos C, Panoulis C, Toutouzas K, Zografos G, Papalois A. The effect of erythropoietin on platelet distribution width during ischemia reperfusion injury in rats. Turkish Journal of Cerebrovascular Diseases 2014; 20 (1): 18-23. doi:10.5505/tbdhd.2014.55264. 


\section{INTRODUCTION}

Tissue ischemia and reperfusion (IR) remain one of the main causes of permanent or transient damage with serious implications on adjacent organs and certainly on patients' health. The use of erythropoietin (Epo) is a well established knowledge for many years ago. However, even if important progress has been made, satisfactory answers have not been given yet in fundamental questions, such as, by what velocity this factor acts, when should it be administered, and in which dosage. The particularly satisfactory action of Epo in stem blood cells recovery has been noted in several performed experiments. Since a careful literature search (PubMed Medline) was conducted, it was realised that this certain factor has been tried in experiments. However, just few relative reports were found, not covering completely this particular object of action velocity. Also, a lot of publications addressed trial of other similar molecules of growth factors to which the studied molecule also belongs to. In the present study, Epo will be tried to find out whether is able to influence hematologic variables as the platelet distribution width (PDW).

\section{MATERIAL AND METHODS}

Aim of present experimental study was the trial of Epo in rat animal model and certainly in IR protocol. The benefit or not of that particular molecule was studied measuring PDW. This experimental study was approved by Scientific committee of Ippokrateion General Hospital, Athens University, and by Veterinary Address of East Attiki Prefecture. Institutional and national guide for the care and use of laboratory animals was followed.

\section{Experimental groups}

This experimental study was laid out by Exprerimental Research Center of ELPEN Pharmaceuticals Co. Inc. S.A. at Pikermi, Attiki. All of settings including consumables, equipment and substances used, were a courtesy of that S. A. 40 female white Wistar rats of mean weight 247,7 gr [Std. Dev: 34.99172 gr] were used, min weight $\geq$ 165 gr and max weight $<320$ gr. They spent in laboratory for 7 days before experimentation with easy access to water and food. They were randomly assigned in the following experimental groups (10 animals in each group). The experiment was acute, that is, the animal usege was completed by following experimental set of times without awakening and preservation of the rodents.

1. Ischemia for $45 \mathrm{~min}$ followed by reperfusion for $60 \mathrm{~min}$ (group A).

2. Ischemia for $45 \mathrm{~min}$ followed by reperfusion for 120 min (group B).

3. Ischemia for 45 min followed immediately by Epo intravenous (IV) administration and reperfusion for $60 \mathrm{~min}$ (group $\mathrm{C}$ ).

4. Ischemia for $45 \mathrm{~min}$ followed immediately by Epo IV administration and reperfusion for 120 $\min$ (group D).

The molecule Epo dose was $10 \mathrm{mg} / \mathrm{Kg}$ body weight of animals.

The experiment was beginning by prenarcosis and general anesthesia administration to the animals. Their electrocardiogram and acidometry were continuously monitored. The inferior aorta was prepared so as its blood flow could be excluded by forceps. After exclusion, the protocol of IR was applied, exactly as described in experimental groups. The molecules were administered at the time of reperfusion, through inferior vena cava catheterization which had been carried out after general anesthesia. The PDW measuring was performed at these time points:

1. After 60 min of reperfusion (groups A and C),

2. After 120 min of reperfusion (groups B and D).

\section{Protocol}

PDW is considered a reliable index being of great clinical diagnostic value concerning special tissue states. Also, rats weight could be potentially a confusing factor, e.g. fatter rats to have greater or less blood PDW levels. This suspicion will be investigated, and will be rejected. Rats underwent general anasthesia by initial intramuscular (IM) administration of 0.5 cc compound, constituted by 0.25 cc xylazine, [25 cc, $20 \mathrm{mg} / \mathrm{cc}$ ] and $0.25 \mathrm{cc}$ ketamine hydrochloride [1000,100mg/cc, 10cc]. Every handling was fully complied with internationally accepted guidelines including the Helsinki Declaration, and guidelines for Good Clinical Practice and Good Laboratory Practice. 0.03 cc butorphanol [10mg/cc, 10cc] anaesthetic agent was administered subcutaneously (SC) 
before laparotomy. Continuous oxygen supply was administered during the whole experiment performance. Ischemia was caused by clamping inferior aorta over renal arteries for 45 min after laparotomic access. Reperfusion was achieved by removing clamping and inferior aorta patency reestablishment.

\section{Control groups}

20 control rats (controls: 1 - 20) mean weight 252.5 gr [Std. Dev: 39.31988 gr] suffered by ischemia for $45 \mathrm{~min}$ followed by reperfusion.

Group A: Reperfusion which lasted $60 \mathrm{~min}$ concerned 10 controls rats of mean weight $243 \mathrm{gr}$ [Std. Dev: 45.77724 gr], mean PDW levels $16.06 \%$ [Std. Dev: 0.2547331\%] (Table 1).

Group B: Reperfusion which lasted $120 \mathrm{~min}$ concerned 10 controls rats of mean weight $262 \mathrm{gr}$ [Std. Dev: 31.10913 gr], mean PDW levels $15.83 \%$ [Std. Dev: 0.2540778 \%] (Table 1).

Table 1. Weight and mean platelet distribution width levels and standard deviation of groups.

\begin{tabular}{cccc}
\hline Groups & Variable & Mean & SD* \\
\hline A & Weight & $243 \mathrm{gr}$ & $45.77724 \mathrm{gr}$ \\
& PDW & $16.06 \%$ & $0.2547331 \%$ \\
B & Weight & $262 \mathrm{gr}$ & $31.10913 \mathrm{gr}$ \\
& PDW & $15.83 \%$ & $0.2540778 \%$ \\
C & Weight & $242.8 \mathrm{gr}$ & $29.33636 \mathrm{gr}$ \\
& PDW & $16.32 \%$ & $0.2898274 \%$ \\
D & Weight & $243 \mathrm{gr}$ & $32.84644 \mathrm{gr}$ \\
& PDW & $16.01 \%$ & $0.2424412 \%$ \\
\hline
\end{tabular}

\section{Erythropoietin group}

20 Epo rats (L: 1 - 20) of mean weight 242.9 gr [Std. Dev: 30.3105 gr] suffered by ischemia for $45 \mathrm{~min}$ followed by reperfusion in the beginning of which $10 \mathrm{mg}$ Epo/kg body weight were IV administered.

Group C: Reperfusion which lasted $60 \mathrm{~min}$ concerned 10 Epo rats of mean weight $242.8 \mathrm{gr}$ [Std. Dev: 29.33636 gr], mean PDW levels $16.32 \%$ [Std. Dev: 0.2898274 \%] (Table 1).

Group D: Reperfusion which lasted $120 \mathrm{~min}$ concerned 10 Epo rats of mean weight $243 \mathrm{gr}$ [Std. Dev: $32.84644 \mathrm{gr}$ ], mean PDW levels $16.01 \%$ [Std. Dev: $0.2424412 \%$ ] (Table 1).

Every weight rats group initially was compared with other one from 3 remained groups applying statistical paired t-test (Table 2). Some weight correlations may result statistically significant. In case of any emerging significant difference among PDW, will be investigated whether owed in probable significant weight correlation. Along, every PDW rats group initially was compared with other one from 3 remainder groups applying statistical paired t-test (Table 2). Generalised linear models (glm) were applied with dependant variable the PDW levels and independent variables the erythropoietin administration or no, the reperfusion time and their interaction.

Table 2. Statistical significance of mean values difference for groups after statistical paired t test application.

\begin{tabular}{cccc}
\hline DG $^{\dagger}$ & Variable & Difference & p-value \\
\hline A-B & Weight & -19 gr & 0.2423 \\
& PDW & $0.23 \%$ & 0.0394 \\
A-C & Weight & 0.2 gr & 0.9900 \\
& PDW & $-0.26 \%$ & 0.1059 \\
A-D & Weight & 0 gr & 1.0000 \\
& PDW & $0.05 \%$ & 0.6854 \\
B-C & Weight & $19.2 \mathrm{gr}$ & 0.2598 \\
& PDW & $-0.49 \%$ & 0.0037 \\
B-D & Weight & 19 gr & 0.1011 \\
& PDW & $-0.18 \%$ & 0.1081 \\
C-D & Weight & $-0.2 \mathrm{gr}$ & 0.9883 \\
& PDW & $0.31 \%$ & 0.0184 \\
\hline
\end{tabular}

${ }^{\dagger}$ difference for groups

\section{RESULTS}

Erythropoietin administration increased significantly the PDW levels by $0.22 \%[0.034374$ $\%-0.4056259 \%](\mathrm{P}=0.0214)$, in accordance also with paired t-test $(\mathrm{P}=0.0196)$. Reperfusion time decreased significantly the PDW levels by $0.27 \%$ $[-0.4483669 \%-0.0916332 \%](\mathrm{P}=0.0040)$, in accordance also with paired t-test $(\mathrm{P}=0.0012)$. Interaction of erythropoietin administration and reperfusion time increased non significantly the PDW levels by $0.06 \%$ [-0.054648 \% - 0.1819207 $\%](\mathrm{P}=0.0615)$.

Reviewing the above and table 2, the table 3 turns up concerning the increasing influence of erythropoietin in connection with reperfusion time. Inserting the rats weight as independent variable at glm, significant relation does not turns on PDW ( $p=0.6529)$, so as to further investigation is not needed.

\section{DISCUSSION}

As above mentioned, PDW may characterizes special tissue disease states. It worths investigating whether PDW is up to ischemic situations. Indeed, Muscari A et al (1) determined PDW values in patients with coronary heart disease or at risk for stroke in elderly population and associated them with subcutaneous 
Table 3. The increasing influence of erythropoietin in connection with reperfusion time.

\begin{tabular}{lllll}
\hline & & & \multicolumn{2}{c}{$\mathrm{p}$-values } \\
Increase & \multicolumn{1}{c}{$95 \% \mathrm{CI}^{\ddagger}$} & $\mathrm{RT}^{*}$ & t-test & glm \\
\hline $0.26 \%$ & $0.0036453 \%-0.5163544 \%$ & $1 \mathrm{~h}$ & 0.1959 & 0.0471 \\
$0.22 \%$ & $0.034374 \%-0.4056259 \%$ & $1.5 \mathrm{~h}$ & 0.0196 & 0.0214 \\
$0.18 \%$ & $-0.0533189 \%-0.413319 \%$ & $2 . \mathrm{h}$ & 0.1081 & 0.1224 \\
\hline * Reperfusion time & & & \\
₹95\% confidence intervals & & &
\end{tabular}

abdominal fat $(\mathrm{p}=0.02)$, fasting blood glucose $(\mathrm{p}=$ $0.002)$, prevalence of ischemic ECG changes ( $p=$ $0.004)$, prevalence of hepatic steatosis ( $p=0.07)$ and higher homeostasis model assessment (HOMA) index $(\mathrm{p}=0.09)$. Ihara A et al (2) correlated TAT and von Willebrand factor (vWF) significantly positively with PDW between patients with ischemic heart disease (IHD). The same authors (3) found PDW significantly higher in angiographically negative group than positive one of patients ( $\mathrm{p}=0.0146$ ) reflecting the underlying pathophysiological state and subsequent clinical events. Dudley JM et al (4) assessed scored elevated PDW (greater than 2 SD from mean), or presence of clinical ischemia at the outset for distinguishing correct diagnosis of primary thrombocythemia from reactive thrombocytosis (predictive value 89\%). It is remarked that ischemia usually elevates the PDW levels.

Furthermore, it is also worths investigating how erythropoietin influences PDW levels. So, Sowade 0 et al (5) rose the preoperative PDW levels by $3.3 \%$ after administration of $\beta$-epoetin ( 5 x $500 \mathrm{IU} / \mathrm{kg}$ body weight IV over a 14-day period before operation) in patients undergoing cardiac operation without thromboembolic events. Messinezy M et al (6) used the PDW levels and serum Epo values, as clinical evidence of ischemic vascular disease and presence of hypoxia for distinguishing primary from secondary polycythemia. Supine oximeter values < $92 \%$ suggested hypoxemia as mechanism of polycythemia. Half patients had confirmed raised erythropoietin levels. Sharpe PC et al (7) did not noticed change in PDW in patients with chronic renal failure over the six month period receiving recombinant human (r-HuEpo) than control patients. The results suggest that r-HuEPO affects thrombopoiesis and may be part of a group of humoral factors contributing to megakaryocyte development and maturation. Platelets are more reactive and may contribute to the increased risk of thrombosis associated with r-HuEPO.
Westwood $\mathrm{N}$ et al (8) tested criteria as PDW for clinical evidence of ischemic vascular disease and erythroid colony formation from peripheral blood in a serum-free system, assayed either without or with the addition of rhEPO in distinguishing primary polycythaemia from secondary polycythaemias. Yazihan $\mathrm{N}$ et al (9) supposed lipid peroxidation as the main cause of the further secondary damage which starts after mechanical destruction of tissues. They examined whether Epo treatment has neuroprotective properties after spinal cord injury (SCI) on the oxidant and anti-oxidant enzyme systems. They suggested that 150 i.u./kg i.p. Epo, a therapeutic dose in anemic patients, applied after SCI significantly attenuated the oxidative damage in rats, increasing catalase and reducing glutathione, malonyldialdehyde and TNF $\alpha$ levels.

Among the parameters provided, platelet indices are probably the most ignored by clinical laboratories due to the difficulty of standardization, as well as being affected by a range of methodological problems. It has been suggested that each laboratory determines its own reference intervals with the equipment used. Among all platelet indices, PDW has been receiving attention due to its usefulness for distinguishing between reactive thrombocytosis and thrombocytosis associated with myeloproliferative disorder. Farias MG et al (10) recognized that determination of the PDW reference range is fundamental, and the association of this parameter with other platelet indices may be used for the diagnosis and differentiation of several pathologies. Akpinar I et al (11) found that furthermore increased PDW may be a useful predictor of slow coronary flow (SCF) patients because it may cause microvascular blood flow resistance due to impaired cell deformability. Ceylan B et al (12) considered PDW as an independent variable determining the severity of liver fibrosis in patients with chronic HBV infection along with other markers. Alyamac Dizdar E et al (13) associated patent ductus arteriosus with high PDW in preterm infants. Santimone I et al (14) underlined the relation between PDW and inflammation. Zhang KJ et al (15) applied the PDW level in the simple and primary differential diagnosis of thrombocytosisrelated diseases: reactive thrombocytosis, chronic myeloproliferative disease including chronic myeloid leukemia, essential thrombocythemia and polycythemia vera. Boos CJ et al (16) found 
a stepwise increase in PDW - marker of platelet shape change - with increasing severity of 'highrisk' essential or malignant phase or thrombotic complications hypertensive disease. Jurcut $\mathrm{R}$ et al (17) associated high PDW values with worse short-term prognosis of unstable angina patients with a higher number of affected coronary arteries but similar both global atherosclerotic burden and also endothelial dysfunction: high vWF and low brachial flow-mediated dilation. Wasiluk A et al (18) considered an increased PDW vital in diagnosis of hemostatic disorders dysfunction of megakaryocytes and a low gestational age in preterm newborns. Indraccolo U et al (19) used PDW tests for the conservative management of HELLP syndrome. Ravindran R et al (20) found a higher PDW indicative of prothrombotic tendency in coronary artery disease patients. Hyperlipidemia increases the lipid content in platelets and enhances their reactivity. Hyperactive platelets may contribute to accelerated atherogenesis and organized thrombus formation on vascular surfaces. Nearly all authors associate elevating PDW levels either induced or not by Epo, with ominous diseases evolutions.

\section{Conclusion}

Epo administration has significant increasing short-term effects on PDW levels. However, reperfusion time attenuates significantly this effect. Their interaction seems to resemble the action of Epo administration. The following raised question is whether the Epo-induced elevating PDW levels, is the cause or the result of certain diseases pathoprysiology process deterioration. Further human clinical or molecular studies with greater samples will get on make this effect clearer.

Acknowledgment: This study was funded by Scholarship by the Experimental Research Center ELPEN Pharmaceuticals (E.R.C.E), Athens, Greece. The research facilities for this project were provided by the aforementioned institution.

\section{REFERENCES}

1. Muscari A, De Pascalis S, Cenni A, et al. Determinants of mean platelet volume (MPV) in an elderly population: relevance of body fat, blood glucose and ischaemic electrocardiographic changes. Thromb Haemost. 2008 Jun; 99(6): 1079-84.

2. Ihara A, Kawamoto T, Matsumoto K, et al. Relationship between hemostatic factors and the platelet index in patients with ischemic heart disease.
Pathophysiol Haemost Thromb. 2006; 35(5): 388-91.

3. Ihara A, Kawamoto T, Matsumoto K, et al. Relationship between platelet indexes and coronary angiographic findings in patients with ischemic heart disease. Pathophysiol Haemost Thromb. 2006; 35(5): 376-9.

4. Dudley JM, Messinezy M, Eridani S, et al. Primary thrombocythaemia: diagnostic criteria and a simple scoring system for positive diagnosis. Br J Haematol. 1989 Mar; 71(3): 331-5.

5. Sowade O, Ziemer S, Sowade B, et al. The effect of preoperative recombinant human erythropoietin therapy on platelets and hemostasis in patients undergoing cardiac surgery. J Lab Clin Med. 1997 Mar; 129(3): 376-83.

6. Messinezy M, Sawyer B, Westwood NB, et al: Idiopathic erythrocytosis--additional new study techniques suggest a heterogenous group. Eur J Haematol. 1994 Sep; 53(3): 1637.

7. Sharpe PC, Desai ZR, Morris TC. Increase in mean platelet volume in patients with chronic renal failure treated with erythropoietin. J Clin Pathol. 1994 Feb; 47(2): 159-61.

8. Westwood N, Dudley JM, Sawyer B, et al. Primary polycythaemia: diagnosis by non-conventional positive criteria. Eur J Haematol. 1993 Oct; 51(4): 228-32.

9. Yazihan N, Uzuner K, Salman B. Erythropoietin improves oxidative stress following spinal cord trauma in rats. Injury. 2008 Dec; 39(12): 1408-13.

10. Farias MG, Schunck EG, Dal Bó S. Definition of reference ranges for the platelet distribution width (PDW): a local need. Clin Chem Lab Med. 2010 Feb; 48(2): 255-7.

11. Akpinar I, Sayin MR, Gursoy YC, et al. Plateletcrit and red cell distribution width are independent predictors of the slow coronary flow phenomenon. J Cardiol. 2013 Sep 3; pii: S0914-5087(13): 00235-9.

12. Ceylan B, Mete B, Fincanci M, et al. A new model using platelet indices to predict liver fibrosis in patients with chronic hepatitis B infection. Wien Klin Wochenschr. 2013 Aug; 125(15-16): 453-60

13. Alyamac Dizdar E, Ozdemir R, Nur Sari F, et al. Low platelet count is associated with ductus arteriosus patency in preterm newborns. Early Hum Dev. 2012 Oct; 88(10): 8136.

14. Santimone I, Di Castelnuovo A, De Curtis A, et al. White blood cell count, sex and age are major determinants of heterogeneity of platelet indices in an adult general population: results from the MOLI-SANI project. Haematologica. 2011 Aug; 96(8): 1180-8.

15. Zhang KJ, Lu QY, Li P, et al. Significance of platelet parameters and lactate dehydrogenase level in differential diagnosis for thrombocytosis. Zhongguo Shi Yan Xue Ye Xue Za Zhi. 2010 Aug; 18(4): 972-5.

16. Boos CJ, Beevers GD, Lip GY, et al. Assessment of platelet activation indices using the ADVIATM 120 amongst 'highrisk' patients with hypertension. Ann Med. 2007; 39(1): 728.

17. Jurcuţ R, Arsenescu I, Puşcariu T, et al. Is interleukin-18 correlated with endothelial dysfunction and platelet activation in patients with unstable angina? Rom J Intern Med. 2005; 43(3-4): 199-209.

18. Wasiluk A, Osada J, Dabrowska M, et al. Does prematurity affect platelet indices? Adv Med Sci. 2009; 54(2): 253-5.

19. Indraccolo U, Gentile G, Manfreda VM, et al. The development of disseminated intravascular coagulation in hemolysis, elevated liver enzymes, and low platelet count syndrome (HELLP) at very early gestational age. Minerva Ginecol. 2008 Oct; 60(5): 445-50.

20. Ravindran R, Krishnan LK. Increased platelet cholesterol 


\section{Tsompos et al}

and decreased percentage volume of platelets as a secondary risk factor for coronary artery disease. Pathophysiol Haemost Thromb. 2007; 36(1): 45-51.

Turkish Journal of Cerebrovascular Diseases 2014; 20 (1): 18-23 